\title{
Isolation and Characterization of Cellulolytic Bacteria from Historic Documents
}

\author{
Shababa A. Bahjat \\ Adeeba younis Sherif \\ Musa'ab Hani Salih \\ Department of Microbiology / College of Science \\ University of Mosul
}

Received

16 / 05 / 2011
Accepted

15 / 09 / 2011

|لمانصم

يعتبر تآكل وتلف المخطوطات والكتب التاريخية في المكتبات من المشكلات الهامة التي

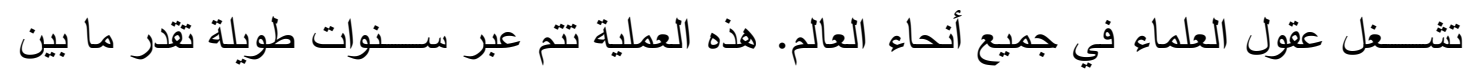
20- أكثر من 200 سنة. ولقد أجريت دراسات مستفيضـة حول ميكانيكية تلوث المواد التاريخية بالاحياء المجهرية ومع ذلك مازالت المشكلة قائمة ليومنا هذا.

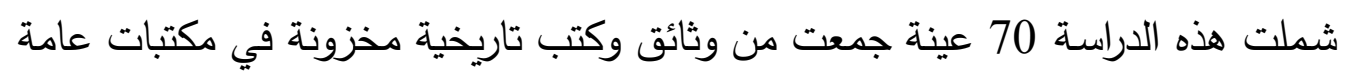

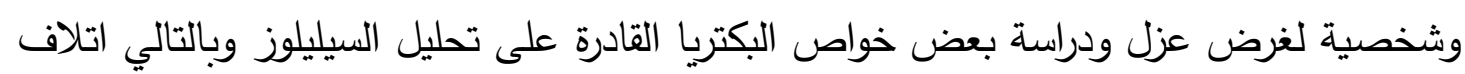

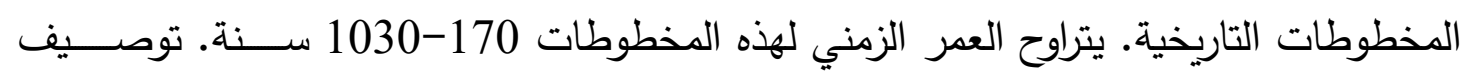

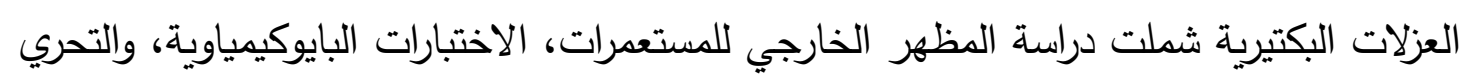

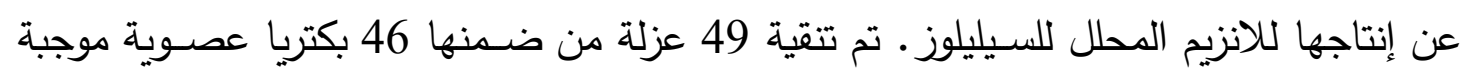

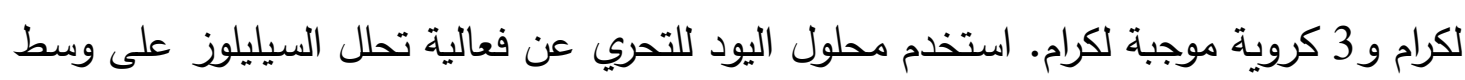
Carboxy methyl cellulose agar

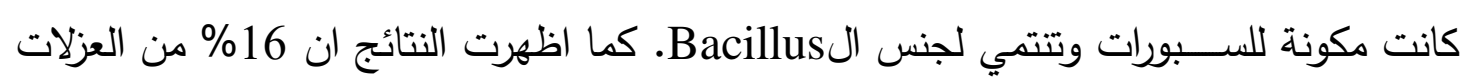

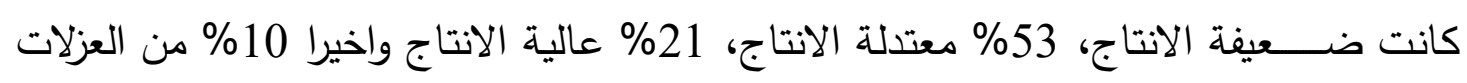

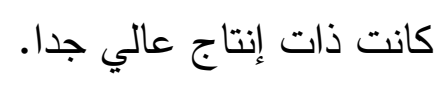

\section{Abstract}

Biodeterioration of paper and parchment in ancient books and documents represents a cause of great concern for libraries and archives all over the world. The degradation processes occurring in paper, typically occur over extended timescales ( 20 to $>200$ years). The study of the 
mechanisms underlying the microbiological attack of historical materials has been widely practiced and still represents one of the main focuses of those institutions and laboratories that are involved in cultural heritage conservation.

A total of seventy historical manuscripts stored in different public and personal libraries were sampled for isolation and characterization of cellulolytic bacteria. The age of the manuscripts varied from 170-1030 years old. The characterization of the bacterial isolates was based on colony morphology, biochemical test and their ability to hydrolyze cellulose.

Fourty nine bacterial isolates including 46 gram positive rods and 3 gram positive cocci were purified for further characterization. Fourty six gram positive isolates were sporeformers belonging to the genus Bacillus. Iodine solution was used to detect cellulolytic activity on CMC agar.. Results have shown that $16 \%$ of the isolates were weak producers, $53 \%$ moderate, $21 \%$ high and $10 \% \mathrm{v}$. high producers.

Keywords: cellulolytic bacteria, historic documents,paper, deterioration. Corresponding author E-mail: shababa_bahjat@yahoo.com

\section{Introduction}

A library is a repository of wisdom of great thinkers of the past and the present. It is a social institution charged with the responsibility of disseminating knowledge to the people. The holdings of the libraries are the priceless heritage of mankind as they preserve facts, ideas, thoughts, accomplishments and evidences of human development in multifarious areas, ages \& directions. Any loss to such materials is simply irreplaceable.

Except a few libraries, all others have paper based reading materials in the form of manuscripts, books, periodicals, paintings, drawings, charts, maps etc.. The basic materials and constituents of the physical entity of these library materials are mostly organic in nature, which are susceptible to natural decay and deterioration. In books, apart from paper the other materials used are board, cloth, leather, thread, ink, adhesive etc... All these materials used are nutritious to some living organisms Paper consists of cellulose fibre, which can be oxidised by atmospheric oxygen, causing deterioration. The products of oxidation can give rise to cracking of the molecular chains. The same occurs if the cellulose is exposed to acid or formaldehyde, which may have been added to the paper during manufacture. However, the same effect occurs from air pollution and chemicals from fixing and development processes (Rhyl-Svendsen, 1999). Deterioration is a change of original state of any material by interaction between the object and the factors of destruction.

The different types of deterioration of the paper based materials are reflected in wear and tear, shrinkage, cracks, brittleness, warping, bioinfestation, discoloration, abrasion, hole, dust and dirt accumulation etc. 
Generally, library materials are susceptible to deterioration by the following factors:-

1- Environmental (climatic) factors like light, heat, humidity and moisture, dust, dirt, and water.

2- Biological factors: - Microorganisms, insects and rodents.

3- Chemical factors

4- Human factors

5- Disasters

The deterioration caused by biological agents such as microorganisms, insects and rodents is generally known as bio-deterioration. Many fungi and bacteria produce serious damage in historic materials, which are decomposed from the impact of specific enzymes, cellulases, proteases, ligninases, and organic acids. The investigations carried out up to now have revealed that at least 200 species of microorganisms can cause color alterations, structural alterations, fragility, and destruction of paper (Mandrioli, 2003). (Florian, 1997) showed biological alterations to historic objects caused by the most common species of microorganisms and insects in museums and archives. It is the moisture content of materials that allows microbial growth, because it determines the water available for the germination of spores and on the casual events that help colonization of materials (insect dispersion, human contamination...). Also, Microbial development in book stores poses two serious risks

- The metabolic production of organic substances that interact with the material. These substances include pigments, enzymes (cellulases and proteases), organic and inorganic acids, chelating agents and other biochemical substances.

Over the years, culturable, cellulase-producing bacteria have been isolated from a wide variety of sources such as composting heaps, decaying plant material from forestry or agricultural waste, the feces of ruminants such as cows, soil and organic matter, and extreme environments like hot-springs, to name a few (Doi, 2008).

The microbial agents that promote the deterioration of parchment are predominantly Bacillus subtilis, Serratia marcescens and Nocardia. (Mandrioli, 2003).

- The presence of detrimental microorganisms and toxins which pose health risks to conservation personnel and visitors.

The objectives of this study are to isolate and characterize microorganisms from historic documents stored in public and personal libraries and to test the ability of these organisms to hydrolyze cellulose.

\section{MATERIALS AND METHODS}

The experiments were done during the period from November 2009-June 2010.

\section{Isolation and screening of cellulolytic bacteria:}


Fragments of paper (2-3 mm width) were collected from the margins of the most degraded pages using a sterile tweezer. These fragments were placed in sterile empty test tubes and transferred to the laboratory (Pinzari, 2010).

Five milliliters of tryptic soy broth was added and all tubes were incubated aerobically at $37^{\circ} \mathrm{C}$. After 24 hour incubation, $\mathrm{O} .1 \mathrm{ml}$. of TSB was spread on Carboxymethylcellulose-agar CMC agar (Hankin, 1977). Carboxymethylcellulose (CMC), a water-soluble cellulose derivative, is a useful substrate for detection of cellulase production because it is degraded quickly by micro-organisms (Mandels, 1976). Iodine solution indicator was prepared by mixing $100 \mathrm{ml}$ of 0.1 molar $\mathrm{HCl}$ with $500 \mathrm{ml}$ of $(1 \%$ Iodine $+2 \%$ Potassium iodide $\mathrm{w} / \mathrm{v}$ ). The final preparation was stored in dark containers at $4^{\circ}$ until use.

Spreading or streaking was occasionally repeated until isolated colonies were obtained before screening for $\mathrm{CM}$ ase activity. Pure isolates were stored on $\mathrm{CMC}$ agar slants at $4^{\circ} \mathrm{C}$ for further characterization.

Efficient plate-screening methods are a prerequisite. Screening for bacterial cellulase activity in microbial isolates is typically performed on carboxymethylcellulose (CMC) containing plates. Kasana (2008) found that Gram's iodine for plate flooding gave a more rapid and highly discernable result. Briefly, 3-5 isolated colonies were inoculated in the center of $\mathrm{CMC}$ agar plates and incubated at $37^{\circ} \mathrm{C}$ for 4 days. Plates were then flooded with Gram's iodine for five minutes, excess iodine was then discarded and zones of hydrolysis were observed.

The bacterial isolates were presumptively identified by means of morphological examination and some biochemical characterizations. The parameters investigated included Gram reactions, endospore formation, catalase production, Voges-Proskauer (V-P) reaction, catalase production, starch hydrolysis, citrate utilization and blood hemolysis. The results were compared with Bergey's Manual of Determinative Bacteria (Holt, 1987).

\section{Results and discussion}

A total of seventy samples of deteriorated old documents, books ... etc. stored in public or personal home libraries were included in the present study. The oldest document was published 1030 years ago while the most recent sampled document was 170 years old. Fourty nine bacterial isolates including 46 gram positive rods and 3 gram positive cocci were purified for further characterization:

1) Colony morphology: Colony morphology was highly variable, often growing as large to very large gray-white, dry to wet (figure 1), 


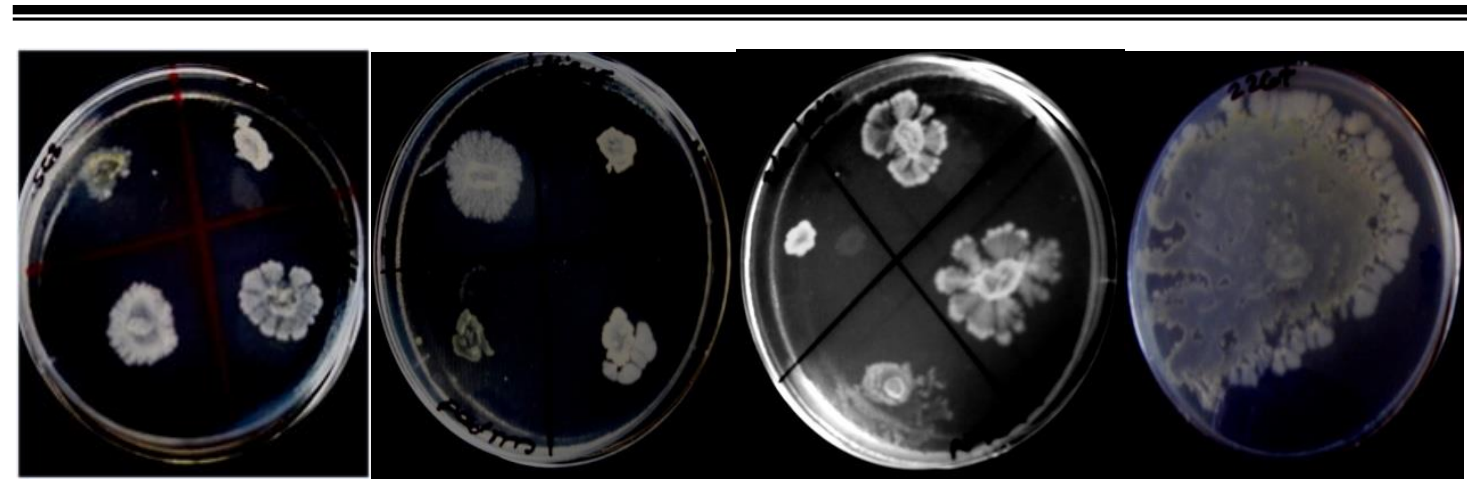

Figure (1): Colony morphology of some bacterial isolates showing typical branching and spreading outgrowth from the edge.

2) Stains: Smears were stained by gram and endospore or Schaeffer and Fulton staining method (Simbert, 1994).

3) Screening of cellulase-producing bacteria was done according to (Kasana, 2008) on CMC selective agar. After 4 days incubation, plates were flooded with Gram's Iodine solution for 3 to 5 min according to (Kasana, 2008) in order to observe zone of clearance around the colony (figure 2).

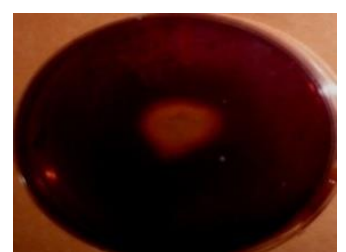

A (+) weak

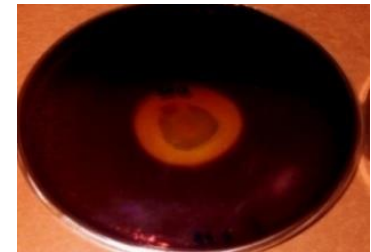

B (++) moderate

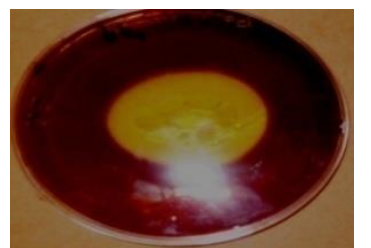

$\mathrm{C}(+++)$ high $\quad \mathrm{D}(++++) v$. high

Figure (2): Grading of cellulase activity using iodine indicator.

4) Hemolytic activity: The ability of isolates to produce hemolysin was done using blood agar media. Pure culture was streaked and incubated aerobically at $37^{\circ} \mathrm{C}$ for 24 hours.

5) Starch hydrolysis test: Isolated colonies were streaked on starch agar. After 24 hours incubation the plate was flooded with lugol's iodine. Clear halos indicated positive results (figure 3 ).

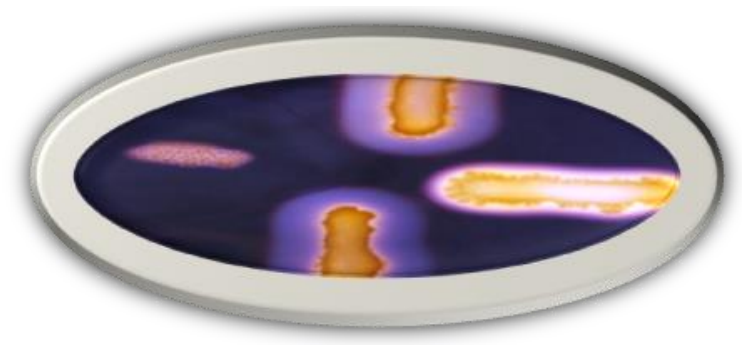

Figure (3): Starch hydrolysis test.

6) Catalase test: $3 \%$ hydrogen peroxide was used to test catalase enzyme activity.

7) Citrate utilization test: Slants of Simmon's citrate agar were streaked and incubated for 24 hours.

8) Voges-Proskauer test: Table (1) shows the biochemical characteristics of the isolates. 
Table (1): Biochemical characteristics of cellulolytic isolates. (nd*): no data

\begin{tabular}{|c|c|c|c|c|c|c|c|c|}
\hline $\begin{array}{l}\text { Isolate } \\
\text { no. }\end{array}$ & $\begin{array}{l}\text { Gram } \\
\text { stain }\end{array}$ & Spore & $\begin{array}{l}\text { Cellulase } \\
\text { production }\end{array}$ & VP & $\begin{array}{l}\text { Blood } \\
\text { hemolysis }\end{array}$ & $\begin{array}{l}\text { Citrate } \\
\text { utilization }\end{array}$ & $\begin{array}{l}\text { Starch } \\
\text { hydrolysis }\end{array}$ & Catalase \\
\hline $1-2 y$ & $\mathrm{G}+$ bacilli & + & ++ & - & - & - & + & + \\
\hline 2- 17 & $\mathrm{G}+$ bacilli & + & +++ & + & +++ & + & + & - \\
\hline $3-20 a$ & $\mathrm{G}+$ bacilli & + & ++ & + & - & + & & + \\
\hline $4-20 b$ & $\mathrm{G}+$ bacilli & + & ++ & - & - & - & + & + \\
\hline $5-2 p$ & $\mathrm{G}+$ bacilli & + & ++ & - & +++ & + & - & + \\
\hline 6-22 & $\mathrm{G}+$ bacilli & + & + & - & - & + & - & + \\
\hline 7-CEP & $\begin{array}{ll}\text { G+ } & \text { v. } \\
\text { short } & \\
\text { bacilli } & \end{array}$ & + & +++ & - & - & - & + & + \\
\hline 8-22(2) & $\mathrm{G}+$ bacilli & + & +++ & - & + & - & + & + \\
\hline 9-Drm & $\begin{array}{l}\text { G+Long } \\
\text { bacilli }\end{array}$ & + & ++ & - & +++ & + & + & + \\
\hline $10-20 c$ & $\begin{array}{l}\text { G+ Long } \\
\text { bacilli }\end{array}$ & + & ++ & - & - & + & - & + \\
\hline 11-10st & $\mathrm{G}+$ cocci & - & + & + & - & + & + & +++ \\
\hline 12-31 & $\begin{array}{l}\text { G+Thin } \\
\text { short } \\
\text { bacilli. }\end{array}$ & + & + & - & +++ & + & - & +++ \\
\hline $13-23 y$ & $\mathrm{G}+$ bacilli & + & ++ & - & - & - & + & + \\
\hline 14-sc8 & $\mathrm{G}+$ bacilli & + & +++ & + & +++ & - & + & + \\
\hline 15-mic15 & $\mathrm{G}+$ bacilli & + & ++++ & - & + & - & + & + \\
\hline 16-28yel & $\mathrm{G}+$ bacilli & + & ++ & - & - & + & + & + \\
\hline $17-22 \mathrm{~N}$ & $\mathrm{G}+$ bacilli & + & +++ & - & +++ & - & - & + \\
\hline $18-26 \mathrm{~N}$ & G+bacilli & + & ++ & - & & - & + & + \\
\hline $19-22 G+$ & $\begin{array}{l}\mathrm{G}+ \\
\text { bacilli }\end{array}$ & + & ++ & - & - & + & + & + \\
\hline $20-27 N$ & $\mathrm{G}+$ bacilli & + & + & - & +++ & + & + & + \\
\hline $21-21 N$ & $\mathrm{G}+$ cocci & - & +++ & - & +++ & - & + & + \\
\hline $22-28 N$ & G+bacilli & + & ++ & - & +++ & - & + & $\mathrm{Nd}$ \\
\hline $23-24 N$ & $\mathrm{G}+$ bacilli & + & ++ & - & +++ & - & + & - \\
\hline 24-30N & $\mathrm{G}+$ bacilli & + & ++ & - & +++ & - & + & + \\
\hline 25- 30- & $\begin{array}{l}\text { G+ long } \\
\text { bacilli }\end{array}$ & + & + & nd & + & - & + & + \\
\hline 26- $20 \mathrm{~N}$ & $\begin{array}{l}\text { G+ long } \\
\text { bacilli }\end{array}$ & + & ++++ & + & +++ & - & + & + \\
\hline $27-23 N$ & $\mathrm{Nd}$ & + & ++ & - & nd & + & + & nd \\
\hline $28-25 N$ & $\mathrm{G}+$ bacilli & + & nd & nd & +++ & nd & nd & + \\
\hline 29- 20 & $\mathrm{G}+$ bacilli & + & +++ & + & - & - & - & + \\
\hline 30- 2 & $\mathrm{Nd}$ & nd & ++ & - & nd & + & + & + \\
\hline 31- 11/g & $\mathrm{G}+$ bacilli & - & ++ & & +++ & - & + & + \\
\hline $32-16 / g$ & $\begin{array}{l}\text { G+ short } \\
\text { bacilli }\end{array}$ & + & ++ & - & nd & - & + & + \\
\hline $33-6 / g$ & $\begin{array}{l}\text { G+long } \\
\text { bacilli }\end{array}$ & + & ++ & - & nd & - & + & + \\
\hline 34- 18/g & $\begin{array}{l}\text { G+ short } \\
\text { bacilli }\end{array}$ & + & +++ & - & +++ & - & + & + \\
\hline
\end{tabular}




\begin{tabular}{|l|l|l|l|l|l|l|l|l|}
\hline \hline 35-10/g & $\begin{array}{l}\text { G+long } \\
\text { bacilli }\end{array}$ & + & +++ & + & +++ & - & + & + \\
\hline 36- 7/g & $\begin{array}{l}\text { G+short } \\
\text { bacilli }\end{array}$ & + & ++ & - & +++ & - & + & + \\
\hline $\mathbf{3 7 - 4}$ /g & G+ bacilli & + & +++ & + & ++ & - & + & + \\
\hline $\mathbf{3 8 - 1 9 / g}$ & G+bacilli & + & ++++ & - & +++ & - & + & +++ \\
\hline $\mathbf{3 9 - 2 0 / g}$ & G+bacilli & + & ++ & + & +++ & + & + & + \\
\hline $\mathbf{4 0 - 5 / g}$ & G+bacilli & + & ++ & - & +++ & - & + & + \\
\hline $\mathbf{4 1 - 1 4}$ 14 & G+bacilli & + & ++ & + & +++ & - & + & + \\
\hline $\mathbf{4 2 - 2 / g}$ & G+bacilli & + & + & - & +++ & - & + & + \\
\hline $\mathbf{4 3 - 8 / g}$ & G+bacilli & + & +++ & - & +++ & - & + & + \\
\hline $\mathbf{4 4 - 1 / g}$ & G+bacilli & + & ++ & - & +++ & - & + & + \\
\hline $\mathbf{4 5 - 1 3 / g}$ & G+bacilli & + & ++ & + & +++ & - & + & + \\
\hline $\mathbf{4 6 - 1 7 / g}$ & G+bacilli & + & ++ & - & +++ & - & weak & + \\
\hline $\mathbf{4 7 - 9 / g}$ & G+bacilli & + & ++ & nd & +++ & + & + & \\
\hline $\mathbf{4 8 - 3 / g}$ & G+ cocci & - & ++ & - & +++ & + & weak & + \\
\hline $\mathbf{4 9 - 1 5 / g}$ & Nd & nd & ++ & - & nd & - & + & + \\
\hline
\end{tabular}

Ninety four percent of the cellulolytic isolates were found to be endospores-formers belonging to the Bacillus sp. (Table 1). This agrees with the results of (Oyeleke, 2008). Bacillus species are known to produce cellulases, some of which are exploited in the industries (Ariffin, 2006), (Lynd, 2002), (Guiamet, 2008). All isolates of Bacillus obtained were sporeformers, which explains their high prevalence in such stores. Spores in a dormant state are commonly present in the air and on the surfaces of objects. Dispersion of spores is the main cause of contamination in the environment; they produce allergies and other illnesses in people and biodeterioration in historic objects. This genus (Bacillus) consists of a group of aerobic or facultatively anaerobic bacteria with a wide diversity of physiological ability with respect to heat, $\mathrm{pH}$ and salinity. Many species are normally present in soil and in decaying animal and vegetable matter (Akin 1987). Other studies demonstrated that species from Bacillus species played important roles in biodegradation and bioconversion of big molecular compounds (Liu,2004) and Bacillus subtilis as well as Bacillus licheniformis are frequently reported cellulolytic species (Vaillant, 2003).

The genus Bacillus is frequent in archives and libraries; it can attack cellulose, parchment and glues, causing deterioration of the documents. This is more frequent in the case of antique papers, where these microorganisms subsist basically on glue and other non-fibrous components. In combination with phycomycetes, these bacteria can cause significant damage, since they decompose the substances produced by the cellulolytic action of the fungi. Likewise, they produce metabolites such as amylase, cellulase and lactic acid, which cause alterations indicated by acidity, purplish stains and brittleness of paper. Under high relative 
humidity-high temperature conditions, these microorganisms are capable of breaking down paper in 24 hours (Kramer, 1973 ; Vaillant, 2003).

Upon initial screening, it appeared that all of the isolates $(100 \%)$ were able to produce cellulase enzyme. Cellulase producing isolates exhibited considerable variation in cellulolytic activity and this agrees with (Tabao et al., 2010) who claimed that the effectiveness of the cellulases produced by Bacillus spp. probably differs from species to species. Therefore, bacterial isolates were categorized into 4 groups according to the width of inhibition zones; weak (group 1), moderate (group 2), high (group 3), and very high (group 4). The first 2 groups were represented by 16 and $53 \%$ activity, respectively, while groups 3 and 4 were represented by 21 and $10 \%$ activity, respectively (Figure 4 ).

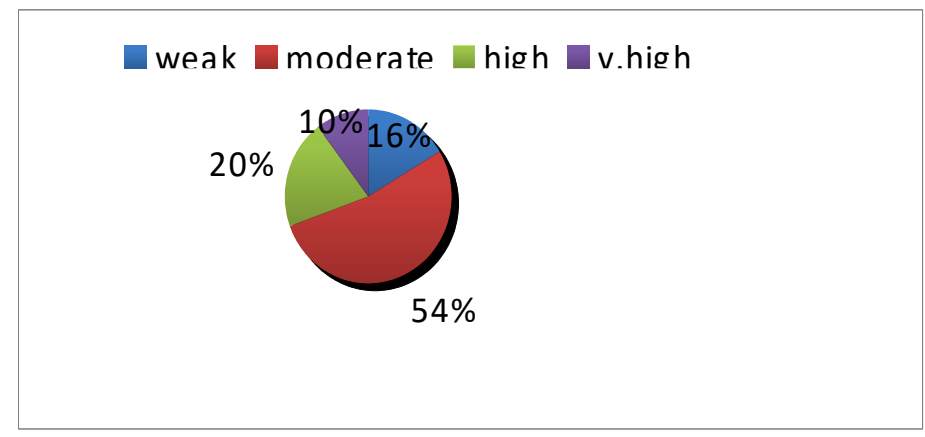

Figure (4): Distribution of the CMC degrading bacterial isolates.

Among bacteria, species in the genera Bacillus, Bacteroides, Clostridium (a common contaminant of proteinaceous materials), Pseudomonas, Streptococcus, Staphylococcus, and some strains of Micrococcus could produce allergic problems and other illnesses Actinomyces are filamentous bacteria that are included in hazard groups. (Nicole, 2001) has published that the most common illness detected in personnel involved in archives and museum conservation were rhinitis, dermatitis, allergic bronchitis, asthma, allergic bronchopulmonary aspergillosis, and hypersensitivity pneumonitis.

It should be considered that microorganisms that do not grow in culture in laboratory conditions could, even so, be present in the environment and on objects. Further diagnosis need to be carried out in order to reach the species level, and this occasionally depends on more than one key in addition to confirmative API $50 \mathrm{CHB}$ identification. In biodeterioration research, molecular biological analyses including polymerase chain reaction (PCR), denaturing gradient gel electrophoresis (DGGE), and the creation of clone libraries, should be applied as a sensitive alternative to conventional cultivation techniques even though they are expensive(Michaelsen, 2010). The development and maintenance of a bacterial community on a shelf of a library or in a single book depends on the spores that reach the material's surface, on the microenvironment 
(temperature, relative humidity, light), and on the water activity of the substrate.

\section{References}

1) Akin, C. (1987). Biocatalysis with immobilized cells. Biotechnol. Genet. Eng. Rev., 5, 319-367.

2) Ariffin H, Abdullah N, Umi Kalsom M.S, Shirai Y, Hassan M.A. (2006). Production and characterization of cellulase by Bacillus pumilus EB3. Int. J. Eng. Tech. 3(1):47-53.

3) Astrid M. Guadalupe P. Flavia P. (2010). Environmental Microbiology .Molecular and Microscopical Investigation of the Microflora Inhabiting a Deteriorated Italian Manuscript Dated from the Thirteenth Century. Microb . Ecol. 60:69-80.

4) Doi R.H. (2008). Cellulases of mesophilic microorganisms: cellulosome and nocellulosome producers. Ann NY Acad Sci. (1125): 267-279.

5) Flavia Pinzari1, Mariasanta Montanari, Astrid Michaelsen and Guadalupe Piñar.(2010). Analytical Protocols for the assessment of Biological damage in Historical Documents. Coalition (19): 6-13.

6) Florian, Mary-Lou E. (1997). Heritage Eaters: Insects and Fungi in Heritage Collections. London: James and James.

7) Guiamet P. S., de la Paz Naranjo, Arenas P. M., Gómez de Saravia S.G., (2008). Differential Sensitivity of Bacillus sp. Isolated from Archive Materials to Plant Extracts. Pharmacologyonline 3: 649658.

8) Hankin L, Anagnostakis S. (1977). Solid media containing carboxymethyl cellulose to detect CM celllulase activity of microorganisms. J. Gen. Microbiol. (98):109-115.

9) Holt, J. G., Williams and Wilkins, Baltimore, MD. (1987). The aerobic endospore-forming rods and cocci. Bergey's Manual of Determinative Bacteriology, 9th ed. p. 670-675.

10) Jyotshna sahoo. Preservation of library materials: some preventive measures. OHRJ vol. XLVII no. 1 p. 105-114.

11) Kasana R.C, Salwan R, Dhar H, Dutt S, Gulati A. (2008). A rapid and easy method for the detection of microbial cellulases on agar plates using gram's iodine. Curr. Microbiol. 57(5):503-507.

23-Kramer G. 1973. Tratado de prevención del papel y de la conservación de bibliotecas y archivos. Dirección general de Archivos y bibliotecas. Madrid: Servicio de Publicaciones del Ministerio de Educación y Ciencias. p. 274.

12) Liu, Y. S., Zhang, J., Liu, Q., Zhang, C. G., and Ma, Q. S.( 2004). Molecular cloning of novel cellulase genes cel9A and cel12A from Baclillus licheniformis GXN151 and synergism of their encoded polypeptides. Curr. Microbiol., 49, 234-238. 
13) Lynd R., Weimer J., William H., Isak S. (2002). Microbial cellulose. Utilization: Fundamentals of Biotechnology. Microbiol. Mol. Biol. Rev.,66: 506-577.

14) Mandels M., Andreotti R,. \& Roche C. (1976). Measurement of saccharifying cellulase. Symposium on Enzymatic Conversion of Cellulosic Materials, Newton, Massachusetts, U.S.A. Biotechnology and Bioengineering, symposium no. 6:21-33).

15) Mandrioli, Paolo, Giulia Caneva, Cristina Sabbioni. (2003). Heritage and aerobiology: Methods and measurement techniques for biodeterioration monitoring. Springer, Kluwer academic publishers.

16) Nolard, Nicole. 20-23 June (2001). Fungal allergies in fungi. Paper presented at conference "Fungi: A Threat for People and Cultural Heritage Through Microorganisms". Abstract for the International Conference.

17) Oyeleke, S. B. and Okusanmi, T. A. (2008). Isolation and characterization of cellulose hydrolyzing microorganism from the rumen of ruminants. African Journal of Biotechnology Vol. 7 (10), pp. 1503-1504.

18) Pinzari, Flavia, Mariasanta Montanari, Astrid Michaelsen and Guadalupe Piñar. (2010). Analytical Protocols for the assessment of Biological damage in Historical Documents. Coalition (19): 6-13.

19) Ryhl-Svendsen, Morten. (1999). An Introduction to the Factors which Deteriorates Photographic Materials, and to Basic Preventive Conservation Notes to a talk given at the Seminar on Preservation and Promotion of the Photographic Heritage in West Africa Programme des Musees De l' Afrique de Lt/West African Museums Programme (WAMP).

20) Smibert, R.M. and Krieg, N.R. (1994). Phenotypic characterization. In: Methods for General and Molecular Bacteriology (Gerhardt, P., Murray, R.G.E., Wood, W.A. and Krieg, N.R., Eds.), pp. 607-654. American Society for Microbiology, Washington, D.

21) Tabao, Nik Shawn, Monsalud,Rosario. (2010). Characterization and identification of high cellulose-producing bacterial strains from Philippine mangroves. Philippine Journal of Systemic Biology vol. IV. Pp. 13-20.

22) Vaillant M, Doménech MT Valentin N. Una mirada hacia la conservación preventiva del patrimonio cultural. Universidad Politecnica de Valencia 2003:150. 